\title{
Another Approach to Staff Status
}

SINCE 1917, with the appointment of an $\mathcal{O}$ assistant librarian with the rank of instructor, qualified staff members of the library of the University of Utah have often been granted the rank of instructor or above. In that year the chief librarian, who held a B.L.S. degree, had the rank of assistant professor. At that time an M.A. degree or its equivalent (B.L.S. degree) was required for such rank and additional training was mandatory before passing beyond it. In 1924 the librarian received a second professional degree, the M.A. degree, and a year later, she was advanced to the rank of associate professor, which was generally reserved for those with the Ph.D. degree or its equivalent. In 1925 three other staff members had the rank of instructor. Two others, neither with the equivalent of the M.A., were ranked as assistants. By 1929 the librarian had been granted the rank of full professor as had several teachers in whose field the doctorate was not commonly found.

Throughout the depression years library school graduates were willing to accept appointments with the rank of assistant. Thus, in 1934 library school graduates held only that rank as did two others without the training.

By 1936 five library school graduates held the rank of instructor. Three other staff members, holding only the B.A. degree, had the rank of assistant only. Such promotions and ratings carried with them, of course, moderate salary increases.

The budgetary factor seemed to be back of the fact that in I940-4I six staff members with library school training held only the rank of assistants. Their salaries unfortunately were also in the assistant bracket, ranging from \$1250 to \$1400. The bottom for instructors at that time was \$1500.

In March 1942 the new librarian, himself classed as an assistant professor since he had only the M.A. degree, recommended that all library school graduates on the staff be granted the rank of instructor and that the assistant librarian be granted the rank of assistant professor in recognition of distinguished service.

These recommendations were approved by the deans' council and then by the faculty administrative council. Some objections were raised to the granting of rank to nonteaching members, but most faculty members stated the promotions were belated.

In the year 1946-47 rank of assistant professor was secured for the reference librarian, the engineering librarian, and the medical librarian. The dean of the faculty raised a question as to teaching titles for nonteachers but waived his objection when it was pointed out that the library has been classified as a department of instruction and investigation rather than as an administrative unit. It was likewise noted that members of the staff do give instruction in how to use the library and in courses for teacherlibrarians.

Since 1942 all appointments of trained librarians have carried with them the stipends of instructors ( $\$ 1500-\$ 2750$ in 1942 ) except that, through oversight in the spring of 1945, one library school graduate was appointed with the rank of assistant. This was rectified in the spring of 1946 without a protest from any who had to ap- 
prove the change in this one salary.

How powerful a welfare factor the rank of instructor can be may be seen from the following list of salary adjustments made since 1942 :

$\begin{array}{rrr} & 1942 & 1947 \\ \mathrm{~A} & \$ 1400 & \$ 2800 \\ \mathrm{C} & 1700 & 2800 \\ \mathrm{C} & 1250 & 2400\end{array}$

It is hoped in the coming year to make further adjustments of from two to seven hundred dollars in order to bring these salaries more nearly into line with those paid instructors for four quarters of service. A tentative budget estimate based on this notion was accepted by the administration without any protest.

For thirty years all persons holding instructor's rank were entitled to sabbatical leave at a fixed stipend of six hundred dollars a year. From 1944 to 1947 they were allowed 60 per cent of the annual income while on leave. Under the four-quarter system, which eliminates sabbatical leaves, it is recommended that librarians participate in the one quarter a year with full pay for an approved program of advanced study.

Prior to June I94I professional staff members with six years of service had received six weeks of vacation with pay. Just before the new librarian was appointed, the president cut the vacation to one month. He said that was more nearly in line with practice in other universities and that it would cause less dissension among the secretarial staffs on the campus. He further remarked he did it before the new librarian came so as not to embarrass the latter and also so as to make it none of his business. Since that time the librarian has secured grants of a full summer with pay for those who wished to attend summer school but has not yet attempted to extend the vacation period. At present he is committed to the theory that salaries rather than vacations attract strong library staff members.

In 1943 the board of regents adopted a set of employment regulations. These regulations clarified many points regarding classification, working week, sick leave, and vacation.

Three academic categories of employees were listed : teachers, research workers, and librarians. An academic employee was carefully stipulated as one having the rank of assistant or above and employed as teacher, research worker, or librarian. Administrators were classed in a separate group, as were clerks and laborers.

With regard to vacation, librarians were granted one month and were included in that group of persons expected to be on duty between quarters. It was further stipulated that the Sunday at one end of each vacation must be counted as well as those which occur within the month. Holidays observed by the university and which occur during a vacation need not be counted. Saturdays are counted as full days in computing vacation or sick leave.

The standard work week for library employees and research workers was listed as 8:30 a.m. to 5:00 p.m., Monday through Friday, and 9:00 a.m. to $I: 00$ p.m. on Saturday. Equivalent periods may be scheduled when necessary. In practice, those who work nights are allowed one hour of travel time and are permitted to work all of their hours before Saturday.

Sick leave accumulates at the rate of one day for every fifteen days of service with up to thirty days a year without question. Upon recommendation of the department head and president, sick leave may be extended to ninety days if certified by a physician. With approval of the president and the board, sick leave may be extended to nine months if colleagues are willing and able to perform the sick member's duties without extra compensation. This last is 
almost an impossibility in the library.

When an employee resigns, if proper notice is given, he may receive his vacation or a salary payment in lieu of this. In practice this recently meant that two retiring staff members who chose to work until June 30 , the end of the fiscal year, were allowed one month's salary in the new year for the vacation which they had earned but not taken.

Since 1942 all prospective appointments have been discussed with the staff, along with the salaries involved. At first there was some bitterness at hiring at \$I 700 where \$1200 had once been the custom. Likewise, when it was discovered that $\$ 50$ to $\$ 100$ was the only differential for three to five years of service, resentment occurred. In fact, until salaries were more nearly adjusted in terms of training and experience, frank discussion was found undesirable. It merely upset people.

In 1946 the faculty, deans' council, and president approved a university-wide regulation that department heads consult their staff members before preparing their annual budget. In addition to watching the salary schedule, the department head is to consider professional attainment, length and nature of experience, efficiency, capability as a research worker, and general service to the university.

There was at first a tendency for staff members to insist that filing, typing, and the like were professional jobs calling for library school graduates. They are now agreed that clerical workers can do many library tasks and that the employment of these workers has not impaired the status of the professional staff.

The faculty council members have come to accept two ideas. One is that men or women of high caliber in library work, like teachers in engineering, need not have the doctorate in order to merit considerable recognition. The other is that we cannot afford people of this caliber for every job in the library.

It is the experience of the writer that most presidents and faculty members are open to approach on such matters as rank, salary, tenure, retirement, sick leave, and vacation privileges for library staff members.

An appeal to equity, asking the same treatment for similar training, with comparisons carefully worked out locally, seems more effective than a statement of what other universities are doing. Yet, if staff members who resign point out some of the advantages of their new jobs, their resignations can help those who remain. If prospective appointees inquire about these things, they too can help. Both groups can be induced to give this assistance.

Above all, however, it is up to the librarian. If he does not ask for the things which will bring a better staff, he will not get them. If he is overawed by doctorates in other fields and if he secretly regards the training of his staff as inadequate, he might at least work for an outline of conditions under which improvement will be possible.

It would seem unreasonable to demand more than the B.L.S. and then not grant full summers and sabbaticals for study. Likewise, staff members should be released for some course work during the week if they wish.

It would seem unreasonable to demand additional training unless that training can be used on the job provided by the college or university. For instance, a Ph.D. might be a fine thing for reference librarians, but most of them could use to better advantage a full-time clerical assistant to do the routine leg and arm work of their desks. 